5. Puchkov, S. V. (2002). Musical computer technology as a new toolkit of modern creativity. Candidate's thesis. St. Petersburg: C-pb. humanity un-t trade unions. [in Russian].

6. Theory of modern composition (2007). Ed. ed. V. S. Cenova. M.: Music [in Russian].

Стаття надійщла до редакції 27.12.2017

УДК 784.58

DOI 10.31723/2524-0447-2018-26-246-255

Руденко Олександр Федорович

https://orcid.org/0000-0002-0368-6445

Викладач кафедри хорового диригування, вокалу та методики музичного навчання навчально-наукового інституту культури і мистецтв

Сумського державного педагогічного

університету ім. А. С. Макаренка sasha798132gmail.com

\title{
УКРАЇНСЬКА ШКОЛА ВОКАЛЬНОГО МИСТЕЦТВА: ТРАДИЦІї ТА СУЧАСНІСТЬ
}

Мета статті - дослідити основні віхи розвитку української вокальної школи, зокрема факти діяльності духовно розвинутих особистостей у докласичний та класичний період становлення українського вокального мистецтва. Наукова новизна роботи полягає у виявленні тенезу тогочасного вокального новаторства, що мала вплив на посткласичні тенденції розвитку мистецтва співу. Методи дослідження. Для досягнення зазначеної мети використано метод вивчення наукової літератури з досліджуваної проблеми та ретроспективний аналіз ідей музичного виконання у різні історичні періоди. Висновки. Навчання мистецтву співу, вивчення фактів традиційності та сучасності у розвитку практичних аспектів вокального навчання - це кропіткий, але необхідний процес, спрямований на формування, збереження та примноження самобутньої музичної національної культури.

Ключові слова: професійна музична освіта, традиції, сучасність вокальне навчання, спів, культура.

(C) Руденко О. Ф., 2018 
Rudenko Olexandr. Lecturer at the Department of Choral Conducting, Vocals and Methods of Musical Education of the Educational and Scientific Institute of Culture and Arts of the Sumy State Pedagogical University. A. S. Makarenko

Ukrainian school of vocal art: traditions and contemporaneity

The Purpose of the article is to study the main milestones of the Ukrainian vocal school development, in particular the facts of the activities of spiritually developed personalities during the early period of the Ukrainian vocal art. Scientific novelty of the work lies in study of contemporary innovation that had an impact on the post-classical trends in the art of singing. Research methods. To achieve this goal, the method of studying scientific literature on the issue under study and the retrospective analysis of ideas of musical performance in different historical periods are used. Conclusions. Learning the art of singing is a painstaking, necessary process, aimed at the formation, preservation and enhancement of a distinctive musical culture.

Keywords: professional musical education, traditions, modern vocal education, singing, culture.

Руденко Александр Федорович, преподаватель кафедры хорового дирижирования, вокала и методики музыкального обучения учебно-научного институту культуры и искусств Сумского государственного педагогического университета им. А. С. Макаренко

Украинская икола вокального искусства: традиции и современность

Цель статьи - исследовать основные вехи развития вокального искусства, в частности фактов традиционности и современности в развитии практических аспектов вокального обучения. Научная новизна работы лежит в выявлении генезиса вокального новаторства того времени, которое имело влияние на постклассические тенденции развития искусства пения. Методы исследования. Для достижения поставленной цели использован метод изучения научной литературы по исследованной проблеме и ретроспективной анализ идей музыкального исполнения в различные исторические периоды. Выводы. Обучение искусства пения, изучение фактов традиционности и современности в развитии практических аспектов вокального обучения - это кропотливый, но необходимый процесс, направленный на формирование, сохранение и приумножение самобытной музыкальной национальной культуры.

Ключевые слова: профессиональное музыкальное образование, традиции, современность вокальное обучение, пение, музыкальная культура.

Постановка проблеми. Проблеми професійного вокального навчання, зокрема студентів вищих професійних навчальних закладів, $€$ предметом широкого педагогічного пошуку та обговорень. У цій галузі створено велику кількість методичних розробок і рекомендацій, однак, як вірно зазначив Ю. Алієв, всі вони багато в чому пов'язані 3 попередньою історичною епохою [1]. Саме попередні епохи з їх 
монументальністю та багатогранністю несуть у собі велику кількість протиріч і безумовно, впливають на сьогоденну вокальну культуру та професійну освіту.

Кожна епоха породжувала видатних митців-вокалістів, що спираючись на здобутки своїх попередників, примножували досвід вокального надбання і розуміння того, що мистецтво повинно сприяти не лише власне музичній освіті особистості, а й вихованню їі моральних та етичних цінностей. У цьому контексті важливим постає питання виховання молодих митців що стануть основою майбутнього нації, носієм української пісенності, культури та етносу в цілому.

Мета статті - дослідити основні віхи розвитку української вокальної школи, зокрема факти діяльності духовно розвинутих особистостей у докласичний та класичний період становлення українського вокального мистецтва

Методи дослідження. Для досягнення зазначеної мети використано метод вивчення наукової літератури з досліджуваної проблеми та ретроспективний аналіз ідей музичного виконання у різні історичні періоди.

Наукова новизна роботи полягає у виявленні генезу тогочасного вокального новаторства, що мала вплив на посткласичні тенденції розвитку мистецтва співу.

Аналіз актуальних досліджень. Аналіз фахової літератури вказує на те, що більшість сучасних наукових праць присвячені вивченню фізіологічних основ, методики постановки та формуванню співочого апарату (В. Багадуров, Л. Дмітрієв, А. Зданович, Н. Лєбєдєва, В. Морозов, П. Органов, С. Ржевкін, Е. Рудаков, Г. Стулова, Г. Фант, В. Чаплін, С. Юдін, В. Юшманов, І. Яковлєва).

Значно менше уваги надається вивченню питань послідовності, традиційності та спадкоємності, у вихованні співака (Н. Єфімова, В. Левко, М. Мелані, В. Сафонова, Г. Стулова, В. Чаплін, Е. Шарма, А. Яковлева, В. Юшманов).

Безумовно необхідно розглядати питання і з позиції історичних подій та тісно пов'язаними з ними всесвітньо відомими співаками та музичними діячами, що мали безпосередній вплив на розвиток та становлення української вокальної школи. Серед них М. Глінка, С. Гулак-Артемовський, М. Донець-Тейсер, С. Крушельницька, А. Соловяненко, А. Кочерга, Є. Мірошніченко, Д. Гнатюк, М. Кондратюк, М. Стефюк, І. Паторжинський, Д. Петриненко, О. Петрусенко, Б. Руденко та багатьох інших. 
Суто практичним питаннями дихання та звукоутворення займались Ю. Барсов, Л. Дмітрієв, В. Морозов, С. Сонк, Р. Юссон.

Важливе теоретично-методологічне значення мають праці Б. Ананьєва, В. Асєєва, Л. Божович, Л. Виготського, П. Гальперіна, В. Зінченка, Г. Іванченка, В. Когана, Н. Літвінова, Б. Ломова, С. Рубінштейна, Б. Тєплова, Д. Ельконіна.

Висвітленням та шляхами вирішення проблем виховання студентів вокалістів у вищих навчальних закладах займаються Е. Абдулін, М. Агін, Л. Алєксєєва, Ю. Алієв, И. Алієв, О. Апраксіна, Т. Бакланова, Н. Ветлугіна, Л. Зорілова, А. Казакова, О. Ланщікова, Е. Петрова, I. Сахнова, Р. Сладкопєвєц, М. Сідорова.

Проблематика у галузі фоніатріі висвітлена в роботах Ф. Засєдатєлєва, А. Єгорова, І. Лєвідова, Л. Работнова.

Питання що пов'язані з професійною підготовкою співаків до виконавської діяльності висвітлені у роботах Н. Гребенюк, Г. Стасько, Т. П. Малишева, В. Морозова, В. Ємельянова, А. Єгорова, М. Єгоричева.

Водночас, питання становлення українського вокального мистецтва, навчання мистецтву співу на національних засадах, розглянуті недостатньо. Прикладом цьому може слугувати аналіз «Граматики мусікійської» М. Дилецького. Автори, що розглядають цей важливий посібник, зосереджуються на його музично-теоретичній частині, оминаючи увагою музичні тенденції того часу та значення, яке вони мали у практичній роботі.

Виклад основного матеріалу. Історичне коріння виховання засобами музики сягає у стародавні часи. Антична доба оголосила музичну освіченість як важливий складник гармонійної особистості.

Вокальне виховання з'явилося у середньовіччі. «Повість временних літ», створена літописцем Нестором, вказує на те, що у відкритих князем Володимиром християнських школах велика увага приділялася співу як невід'ємній частині Богослужіння. 3 часом спів стає важливою складовою церковного хору. В основу підготовки покладалась триєдність читання, писання і співу, також використовувались методи хейрономії та навчання на слух. Ці методи, під різними назвами, застосовувались з певними видозмінами до Нового часу й актуальні по сьогоднішній день.

Навчання співу на Київській Руси до XVII сторіччя було зосереджено у руках окремих вчителів та співаків. Незважаючи на крюковий запис нот, уміння тримати звук на одній заданій висоті, знання 
щодо напряму руху звуків у розспівах, важливості дикції, динаміки, характеру виконання вважалось пріоритетним. Тогочасні вчителі повинні були майстерно володіти технікою співу та мати практику.

Просвітницькі реформи XVIII сторіччя посилили розвиток співочої освіти станового характеру. Це привело до відкриття архієрейських шкіл, духовних семінарій, училищ і т.п. Про досягнення у цій галузі може свідчити факт відкриття школи у 1738 році у місті Глухові, до якої збирали вокально обдарованих малолітніх хлопчаків, яких потім відправляли до Петербургу для подальшого навчання співу та грі на музичних інструментах у Придворній співочій капелі.

Починаючи з 60-х років XIX ст. вчителі співу спирались на методичні напрацювання церковного співу з додаванням народних пісень. Інколи музичний матеріал спрощувався, іноді ускладнювався, в залежності від потреб. Найважливіше місце, на той час, обіймав хоровий спів, у процесі якого відпрацьовувались отримані знання та навички, відбувалось ознайомлення з кращими зразками вокальнохорового мистецтва.

Як вже зазначалося, старовинна церковна музика багато в чому спиралась на вміння співати та промовляти на одному звуці. Саме на використанні цього стародавнього прийому побудував свою методику О. Карасьов (1854-1914). У ній чітко простежується спадкоємність навчання музики, що розпочинається із засвоєння одного звуку (до першої октави), з поступовим додаванням по одному звуку. Як музичний репертуар використовувались і церковні мелодії, і народні. Схожу методику запропонував і П. Мироносицький. Такі системи дозволяли за досить невеликий проміжок часу досягнути певних позитивних результатів.

Зазначимо, що згодом методика навчання співу на одному звуці отримала неоднозначні оцінки. Зокрема, у посібнику Л. Дмітрієвої та Н. Черноіваненко «Методика музичного виховання» (1984) вказано, що вона «відображає схоластику та формалізм навчання того часу. I хоча завдяки чіткій послідовності досягалась певна чистота інтонування і добре засвоювавсь музичний матеріал, система була протиріччям природі музики та подавляла творчий початок» $[5,13]$.

Проте, праці О. Карасьова «Церковний спів» витримала не одне видання й активно використовується і у наші дні. Тільки вказана О. Карасьовим початкова нота носить назву «примарний тон», тобто розширення діапазону йде не від конкретного звуку, а від ноти, найбільш зручної для співу. Ця методика досить популярна у вокальній 
практиці, особливо на початковому етапі, отримає подальшій розвиток у викладацькій діяльності видатних українських співаків.

На превеликий жаль обсяги статті не дозволяють ретельно розглянути трансформацію та розвиток вокального мистецтва в Україні та його подальшого становлення протягом кінця XVIII та XIX сторіччя. Але, безсумнівно, кращі з цих принципів і методів дали паростки не тільки для фахового навчання вокалістів-професіоналів, а й сприяли усвідомленню важливості національного музичного мистецтва. Безумовно, що таке поняття як «школа співу» не може виникнути без наявності професійної музичної культури та існувати відокремлено від національної композиторської школи. Видатний співак та викладач Д. Аспелунд у своїй праці «Розвиток співака та його голос» дав таке визначення поняття вокальної школи «вокально-педагогічна школа - це конкретна, цілеспрямована, організована система підготовки нових поколінь співаків і педагогів для конкретної діяльності, що історично змінюється» $[2,16]$.

Становлення національної вокальної школи тісно пов'язане $з$ іменем засновника української класичної музики Миколи Лисенка. Його творчість ввібрала в себе кращі зразки українського мистецтва. Добре розуміючись на особливостях психологічного складу української нації, тяжіннях у музичній культурі, історичного розвитку вокальних принципів, Микола Віталійович зумів визначить основні напрямки розвитку вокального мистецтва у своїй композиторській та педагогічній діяльності майже на сторіччя вперед.

Важко переоцінити значення музично-драматичної школи відкритої у Києві у 1904 році. Школа давала вищу мистецьку освіту. До спеціальних дисциплін належали: сольний спів, гра на скрипці, віолончелі, фортепіано, оркестрових інструментах, теорія музики і композиції, диригування (хорове та оркестрове) та ін. Вивчались музично-теоретичні дисципліни, італійська мова. До школи запросили відомих педагогів Г. Любомирського та О. Вонсонську (скрипка), професора О. Мишугу, О. Муравйова (сольний спів), М. Старицьку (драма). М. Лисенко викладав музично-теоретичні дисципліни та композицію. Створюючи навчальний заклад М. Лисенко ішов традиційним шляхом притаманним більшості геніальних композиторів що піклуються про створення та пропаганду саме національної музики. Для виконання яскравих задумів композитору була вкрай необхідна передова система навчання, що вже давала чудові результати у європейських державах. Саме для досягнення своєї мети композитор відмовляв собі 
підчас у необхідному. Так у 1903 році, коли громада зібрала кошти щоб композитор зміг придбати власне житло Микола Віталійович відповів що зможе і надалі прожити без нього, а ось без школи ніяк. І на зібрані кошти, у 1904 році, відкрив свою мрію - музично-драматичну школу. Авторитет М. Лисенка як громадського діяча, композитора та особистості був настільки впливовим, що невдовзі викладацький склад почав поповнюватись найвпливовішими постатями у галузі мистецтва.

У 1905 році він запросив до Києва на посаду професора сольного співу музично-драматичної школи Олександра Мишугу. Уславлений маестро погодивсь, розірвавши контракти і відмовившись від гастролей за кордоном. О. Мишуга був бажаною особою на всіх головних сценах Європи. Наприкінці XIX та на початку XX ст. його ім'я було поряд із Соломією Крушельницькою, Енріко Карузо, Тітта Руффо, Федором Шаляпіним. Вихованець італійської школи «бельканто» чарував слухачів виразним фразуванням, чудовою кантиленою, драматичним талантом.

З 1912 року співак працює у Варшаві. У нього багато учнів з Києва та Львова. Мишуга мріє відкрити школу співу при Музичному інституті ім. М. Лисенка. Прикладом у цій справі Мишузі послужив його вчитель, професор співу Валерій Висоцький. Знаменитий бас, учень Франческо Ламперті, що співав в Італії, а по закінченні кар'єри, відкрив власну вокальну школу у Львові. Висоцький виховав цілу плеяду оперних співаків вищого рівня, у нього навчалася й українська співачка Соломія Крушельницька, про яку Джорджо Папасольї писав: «Пройнята почуттям надзвичайної гідності, вона була шляхетною, люб'язною і щирою, а в характері іï̈ легко вгадувалися риси слов'янської душі...» [6, 136].

Про свого вчителя О. Мишуга згадув так: «А мій професор Висоцький умів відразу пізнати мою вразливу натуру, відкрив мені таємниці красивого співу, і я ввесь душею і тілом віддався йому під опіку і слухав його науки, його рад і вказівок артистичних та переживав у тих студіях розкіш несказану...» $[4,29]$.

Мишуга вважав що існує три засоби видобування звуку:

- з закритими вустами в ніс, в маску при піднятому корені язика і опушеному м'якому піднебінні (мичання, мормарандо);

- з відкритими вустами (мичання, мормарандо);

- звичайний спів відкритим горлом (корінь язика максимально опущений і відтягнутий від задньої стінки горла), за активною участю язика, губ, зубів. 
О. Мишуга вчив тому що зараз називають вокальною технологією. Як зазначив болгарський дослідник М. Марков технологія - це «засіб реалізації людьми конкретного складного процесу шляхом розподілення його на частки послідовних взаємопов'язаних процедур і операцій, що виконуються більш або менш однозначно і мають на меті досягнення високої ефективності» $[7,20]$. Тобто по суті це - методи, засоби та дії поетапного досягнення мети.

Траплялось що він декілька місяців тримав учня на двох, трьох, або чотирьох нотах не дозволяючи співати самостійно обраний репертуар. Його учень Щербаківський згадував що О. Мишуга міг тримати у цьому діапазоні іноді до двох років, і самостійно співати щось без його дозволу не дозволялось.

О. П. Мишуга виховав цілу плеяду уславлених співаків. Серед них М. Микиша (один з кращих тенорів в період з 1910 по 1930), Я. ВайдаКоролевич (відома польська виконавиця), М. Донець-Тессейр (була провідною солісткою Київської опери, а також професором Київської консерваторії), О. Любич-Парахоняк (професор Петербурзької консерваторії) та багато інших.

Львівська вокальна школа, що була створена в Консерваторії Галицького Музичного Товариства у другій половині XIX століття, вже займала гідне місце в європейському вокальному світі.

Польська дослідниця Анна Солярська-Захута так описувала навчальний заклад: «У кінці ХІХ століття в консерваторії Галицького Музичного Товариства існувала прекрасна школа співу під керівництвом Валерія Висоцького. Завдяки перейнятому від італійського співака Ламперті методу, що полягав у тренуванні емісії голосу, досконалому фразуванню й виразній дикції, учні Висоцького здобували тріумфи на оперних сценах світу» [8, 224].

Справжньою перлиною школи була постать Соломії Крушельницької. ІІЇ потяг до навчанню мистецтву співу розкривається в девізі що обрала собі співачка «Здобути, або дома не бути» [3, 20]. Все життя вона послідовно втілювала у власній вокальній та педагогічній праці основні принципи італійської школи bel canto. Важливим постулатом bel canto є правило: Si canta col meccanismo, non colla voce - співати слід за допомогою механізму, а не голосом. Соломія Крушельницька любила повторювати учням: «Співати треба не голосом, а процентами $з$ голосу».

Підсумовуючи вищезгадане можна стверджувати що вокальна школа сучасної України це самобутня мистецька культура яка не тіль- 
ки формувалась під впливом кращих європейських надбань та технологій, а і сама своїми традиціями та митцями впливала на формування європейської культури.

Висновки. Навчання мистецтву співу, вивчення фактів традиційності та сучасності у розвитку практичних аспектів вокального навчання - це кропіткий, але необхідний процес, спрямований на формування, збереження та примноження самобутньої музичної національної культури. Вважаємо, що шляхи становлення української вокальної школи необхідно досліджувати більш ретельно. Саме постійна спадкоємність, помножена на професіоналізм сучасного виконавця, дає високий результат.

Тому вважаємо доцільним дослідження впливу минулих тенденцій та традицій на створення сучасних вокальних методик. Більш ретельний розгляд важливості спадкоємності, в свою чергу, допоможе глибше зрозуміти та по новому поглянути на виникнення новітніх тенденцій.

\section{СПИСОК ЛІТЕРАТУРИ}

1. Алиев Ю. Настольная книга школьного учителя - музыканта. М. : Гуманит. изд. центр ВЛАДОС, 2003. 336 с.

2. Аспелунд Д. Развитие певца и его голоса. М. - Л. : Музгиз, 1952. 192 с.

3. Герета. І. Музей Соломії Крушельницької: [нарис-путівник]. Львів: Каменяр, 1978. $58 \mathrm{c.}$

4. Деркач І. Видатний співак. Львів: Каменяр, 1964. 119 с.

5. Дмитриева Л., Черноиваненко Н. Методика музыкального воспитания в школе. Учеб. для учащихся пед. уч. по спец. 03.05.00 «Муз. воспитание», 03.07.00 «Преподавание в начальных классах общеобразоват. шк.». М. : Просвещение, 1989. $207 \mathrm{c}$.

6. Соломія Крушельницька. Спогади. Матеріали. Листування. У 2-х ч. Ч. 1: Спогади / вступ. ст., упор., прим. М. Головащенка. К.: Музична Україна, 1978. $398 \mathrm{c.}$

7. Руденский Е. Введение в психологию праздничного общения. Е. В. Руденский. Кемерово: ОНУУ, 1991.128 с.

8. Solarska-Zachuta A. Teatr Lwowski w latach 1890-1918. Wprowadzenie. Dzieje teatru polskiego. Teatr polski w latach 1890-1918: Zabor austriacki i pruski. Warszawa: Panstwowe Wydawnictwo Naukowe, 1987. - S. 199-228.

\section{REFERENCES}

1. Aliiev Yu. B. (2003) Reference book of the school teacher-musician. Moscow, Russia, Humanit. izd. centr VLADOS [in Russian].

2. Aspelund D. (1952) The development of the voice of the singer. Muzghyz [in Russian]. 
3. Hereta. I. (1978) Museum of Solomiya Krushelnitska: [drawing-way]. Lviv: Kameniar, p. 58. [in Ukrainian].

4. Derkach I. (1964) Popular vocalist. Lviv: Kameniar [in Ukrainian].

5. Dmitriieva L., Chernoivanenko N. (1989) Technique of musical education at school. Moscow, Russia, [in Russian].

6. Solomiia Krushelnytska (1978). Memoirs. U 2-kh ch. Ch.1: Spohady. Ukraina. Kyiv, p. 398. [in Ukrainian].

7. Rudenskyi E. (1991) Introduction to the psychology of festive communication. Kemerovo. ONUU [in Russian].

8. Solarska-Zachuta A. Teatr Lwowski w latach 1890-1918. Wprowadzenie. / Dzieje teatru polskiego. Teatr polski w latach 1890-1918: Zabor austriacki i pruski. - Warszawa: Panstwowe Wydawnictwo Naukowe, 1987. p. 199-228. [in Polish].

Стаття надійшла до редакції 13.12.2017

УДК 787.79(477)

DOI 10.31723/2524-0447-2018-26-255-266

Ірина Сергї̈вна Дружга

https://orcid.org/0000-0002-9741-2874,

здобувач кафедри історії української музики

та музичної фольклористики Національної музичної

академії імені П. І. Чайковського

minkyltyru0608@gmail.com

\section{МЕТОДИЧНІ НАПРАЦЮВАННЯ БАНДУРИСТІВ ЗІНОВІЯ ШТОКАЛКА ТА ВАСИЛЯ ЕМЦЯ}

Мета дослідження - проаналізувати методичні разробки, видані за кордоном: «Кобзарський підручник» Зіновія Штокалка і підручник «Кобза i кобзарі» - Василя Ємия. Методологія дослідження - застосовується аналіз робіт: «Кобзарський підручник» $i$ «Кобза і кобзарі». Наукова новизна полягає в більш комплексному дослідженні перших підручників гри на бандурі, виданих за кордоном. Їх значення для написання нових на основі вже існуючих досліджень бандуристів. Висновки. Таким чином, перші підручники Василя Смия та Зіновія Штокалка є основою для удосконалення наукової літератури. Написання нових шкіл гри на бандурі з освітленням нових професійних завдань. Удосконалення прийомів, способів звуковидобування на бандурі, удосконалення конструкції інструмента. Популяризація бандурного мистецтва через поєднання в репертуарі не тільки творів світової музичної класики, а також традиційного автентічного українського репертуару значно розширили виконавські риси інструменту. I тим самим не тільки створили сприятливі умови для виступів

() Дружга I. C., 2018 